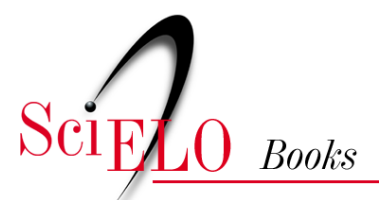

\title{
24. Maculo: a Estranha Doença dos Escravos Africanos
}

\author{
Joffre Marcondes de Rezende
}

\section{SciELO Books / SciELO Livros / SciELO Libros}

REZENDE, J. M. Maculo: a Estranha Doença dos Escravos Africanos. In: À sombra do plátano: crônicas de história da medicina [online]. São Paulo: Editora Unifesp, 2009, pp. 231-236. História da Medicina series, vol. 2. ISBN 978-85-61673-63-5. https://doi.org/10.7476/9788561673635.0025.

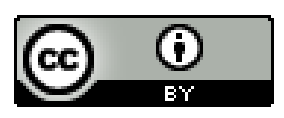

All the contents of this work, except where otherwise noted, is licensed under a Creative Commons Attribution 4.0 International license.

Todo o conteúdo deste trabalho, exceto quando houver ressalva, é publicado sob a licença Creative Commons Atribição 4.0.

Todo el contenido de esta obra, excepto donde se indique lo contrario, está bajo licencia de la licencia Creative Commons Reconocimento 4.0. 


\title{
24
}

\section{Maculo: a Estranha Doença dos Escravos Africanos}

\author{
NOTICIAS \\ DO QUE HE O \\ ACHAOUE \\ DO BICHO, \\ D I F F I N I C, A M DO SEU \\ creft améto,fubimento corrupçaó, fina- \\ es; \& cura atè , o quinto grao, ou \\ intenfaó delle, fuas differen- \\ ças , \& cóplicaçoés,com \\ POR MIGUEL DIAS \\ Pimenta,Familiar doS. Of- \\ ficio, \& refidente no Ar- \\ recife de Pernam- \\ buco. \\ L I S B O A. \\ NaOfficina de M I G UEL MANESCAL \\ Impreffor do Santo Officio
}

Frontispicio do livro de Miguel Dias Pimenta.

$\mathrm{M}$

aculo é o principal nome pelo qual era conhecida no passado uma doença comum entre os escravos africanos no Brasil colonial e que, eventualmente, podia acometer também os indígenas e os colonizadores brancos.

A doença tem uma variada sinonímia, entre denominações populares e científicas: popularmente era chamada de "achaque do bicho", "enfermidade do bicho", "corrupção do bicho", ou simplesmente "corrupção", "mal do sesso", "relaxação do sesso". Os indígenas a chamavam de teicoaraíba, e, entre os hispanoparlantes, era conhecida por "el bicho", "mal del culo", "bicho del culo", "enfermedad del guzano". Dentre as denominações eruditas encontramos ulcus et inflammatio (Piso), inflammatio ani (Martius), Retite gangrenosa epidêmica (Manson).

Caracterizava-se por uma retite inflamatória, com afrouxamento do esfíncter externo do ânus, eliminação de muco fétido, ulcerações e prolapso do reto, além de manifestações sistêmicas como febre, cefaleia, dores no corpo, quebrantamento geral e, por vezes, sintomas neurológicos de torpor, sonolência, delírio e coma, terminando com o óbito do paciente. 
Complicava-se, por vezes, com a miiase do ânus e do reto, consequência, certamente, da falta de higiene e do hábito de defecar na superfície do solo, em meio à vegetação, ao alcance das moscas varejeiras. Nesse caso, a doença evoluía com gangrena do reto e morte do doente.

Luis Gomes Ferreyra, que esteve na Bahia e clinicou durante vinte anos no sertão de Minas Gerais, descreve com minúcia a doença em seu livro Erario mineral e refere jamais ter observado a presença de bichos ou larvas no reto dos doentes, chegando a descrer desta possibilidade, que considerava fantasiosa. Por outro lado, refere a existência de casos com obstipação em lugar de diarreia. Todavia, a presença de larvas (bichos) é mencionada por autores que o antecederam.

Gabriel Soares de Sousa, em I 587 , assinala a ocorrência do mal entre os indígenas e o tratamento por eles utilizado com folhas de tabaco, que eles chamavam de "erva-santa": "Deu na costa do Brasil uma praga no gentio, como foi adoecerem do sesso e criarem bichos nele; da qual doença morreu muita soma desta gente, sem se entender de que; e depois que se soube o seu mal, se curaram com esta erva-santa; e curam hoje em dia os atacados deste mal, sem terem necessidade de outra mezinha" (Andrade e Duarte, I956, p. 393).

Conforme nos esclarece Eustáquio Duarte, "era tradicional entre os índios o processo de espremer o sumo de folhas do 'petume' (tabaco) e de outras plantas 'acres' sobre feridas e chagas em que se criavam 'tapurus', nome que emprestavam às larvas parasitas dos dípteros. Com os tupis, sobretudo, aprenderam os europeus a curar 'bicheiras' de toda sorte, em homens como em animais" (Idem, p. 395).

Aleixo de Brito, médico português, que esteve nove anos em Angola e um ano no Brasil, em seu livro escrito em espanhol, Tratado de las siete enfermedades, confirma a ocorrência da miiase e chama ao maculo de "enfermedad del guzano". Refere a existência dessa enfermidade em Angola, Congo e no Estado do Brasil. Segundo suas palavras é "uma doença mui aguda e perigosa; gera-se nos corpos humanos das partes interiores do sesso, onde em poucos dias se criavam chagas corrosivas que logo se corrompiam, e nelas gerava-se, em alguns enfermos, um bichinho ou bichinhos de corpo mole e cabeça dura e negra, os quais roendo aquela carne juntamente com podridão, em poucos dias matavam o paciente" (Idem, ibidem). 
Guilherme Piso ressalta a possibilidade da miiase anal mesmo na ausência da retite: "Sem nenhuma doença intestinal ou qualquer outro sinal precedente insinua-se às escondidas, um seminário de germes numa parte menos sensível, oculto a princípio do próprio doente ou do médico. E então o mal é tido por incurável porque não raro acarreta a gangrena" (Piso, I957, pp. II4-II7).

Inicialmente, Piso considerava a doença como uma entidade peculiar ao Brasil: "Não sei de ninguém que tenha observado este mal em outro lugar da Terra, além do Brasil" (Piso, I948, pp. I66 e 374). Estava mal informado, porque, antes dele, Jacob Bontius havia descrito em seu livro Methodes Medendi uma doença idêntica ao maculo, na Indonésia, então possessão holandesa (Andrade e Duarte, op. cit., p. 395).

Um dos três primeiros livros de medicina escritos no Brasil e que foi publicado em Lisboa em I707, intitula-se Noticias do que he o Achaque do Bicho. Seu autor, Miguel Dias Pimenta, não era médico e dedicavase ao comércio ambulante, ou seja, era um simples mascate. Os outros dois livros são O Tratado Único das Bexigas e do Sarampo, assinado por Romão Mosia Renhipo, anagrama do médico Simão Pinheiro Morão, e Constituição Pestilencial de Pernambuco, de autoria do médico João Ferreyra da Rosa. Os três livros foram reunidos em uma edição monumental, crítica e comentada por Gilberto Osório Andrade e Eustáquio Duarte, com o nome de Morão, Rosa e Pimenta, publicada em 1956 pelo Arquivo Público Estadual de Pernambuco. Esta publicação é hoje uma raridade e, por seu extraordinário valor, merece ser reeditada para sua maior difusão.

A propósito do livro Noticias do que he o Achaque do Bicho, Eustáquio Duarte fez um estudo exaustivo sobre o maculo, com revisão de toda a literatura mundial existente sobre o mal, chegando à conclusão de que não se tratava de doença peculiar ao nosso país e nem de uma doença africana importada com o tráfico de escravos, como sugerira Langaard.

Tratava-se de uma infecção bacteriana disentérica, de ocorrência universal, que poderia ou não complicar-se de miiase do ânus e do reto. A maior prevalência registrada no Brasil devia-se, sem dúvida, às condições precárias em que viviam os escravos "nos barracões de nefasta memória", onde "sucumbiram centenares de vítimas" (Soares, I955, pp. 3-4). 
Provavelmente outras doenças infecciosas, isoladas ou associadas, foram confundidas e rotuladas como "doença do bicho", o que poderia explicar as diferenças encontradas na descrição do quadro clínico pelos autores que escreveram sobre o maculo.

Patrick Manson, em I903, batizou a doença de "retite gangrenosa epidêmica", denominação erudita pela qual a mesma ficou conhecida nos meios acadêmicos e ainda é citada nos livros e tratados sobre doenças infecciosas e parasitárias. Esta denominação não é a mais apropriada, uma vez que a doença era endêmica e não epidêmica, e nem sempre evoluía com gangrena do reto. Manson jamais vira um caso e baseou-se nas informações de um médico de Curaçau, dr. Ackers, que também não tinha experiência pessoal com casos humanos e sim com animais que apresentavam sintomas semelhantes. De acordo com as informações do dr. Ackers, a doença era chamada na Venezuela de "bicho" e "el bicho" (Manson, I904, pp. 389-39I).

A ocorrência do maculo foi também registrada entre os seringueiros da Amazônia, por Murilo Campos: “[...] a moléstia aparece no início das águas, tanto nos seringais, como nas vilas, especialmente nas de Diamantino e Rosário. [...] Na região do Noroeste são muito atacados os seringais de Santana, perto de Arroz Sem Sal, e os de São Manoel de Piratininga. Não faz a moléstia distinção de raças - são atingidos tanto os pretos e caboclos como os estrangeiros" (São Paulo, I970, p. 219).

O tratamento do maculo era principalmente local, feito com clisteres, banhos e introdução no reto de pedaços de limão, supositórios preparados pela maceração de folhas de determinadas plantas, especialmente da "erva-do-bicho", pimenta malagueta, pólvora, sob a forma de massas (pírolas) ou de tiras de pano, ou fios de algodão, embebidos nessas preparações (sacatrapos). Também se usavam clisteres de água de Labarraque (solução de carbonato de sódio saturada de cloro), canforada, fenicada ou creosotada. Nos seringais da Amazônia, as "pírolas eram preparadas com sabão, pólvora e pimenta". Na Venezuela além do limão, empregava-se clister de uma mistura de rum branco com aguardente.

A chamada erva-do-bicho ou erva-de-bicho compreende, do ponto de vista da taxonomia botânica, as diversas plantas dos gêneros Cuphea e Polygonum. Além do seu emprego no maculo, tais plantas também eram usadas como anti-helmínticas e anti-hemorroidárias . 
Sobre a origem da palavra "maculo", Silva Lima, em I 894, comenta que a moléstia tem sido designada por várias denominações, dentre as quais mal del culo, em espanhol, "donde proveio, por contração, maculo" (Idem, p. 22I). Essa interpretação parece-nos equivocada, visto que a palavra maculo já existia na língua quimbundo (makulu), falada em Angola e Guiné, tanto no litoral, como no interior, segundo nos esclarece Jacques Raimundo em sua obra O Elemento Afro-negro na Lingua Portuguesa.

José Maria Bomtempo, médico da corte de d. Pedro I, relata ter sido acometido, quando residia na África, do mal "chamado na língua do Paiz maculo, o qual corresponde a uma enfermidade semelhante e endêmica nesta cidade (Rio de Janeiro) e em toda a América, desde o Equador até a latitude de $23^{\circ} \mathrm{S}$, onde tem o nome de Corrupção" (Idem, p. 220).

É de supor-se que tenha ocorrido exatamente o inverso: o espanhol "mal del culo" é que seria uma adaptação de "maculo", dada a localização da enfermidade e a semelhança morfológica das palavras. O Dicionário Etimológico Resumido, de Antenor Nascentes, de 1966, e os dicionários modernos já abonam a origem africana do termo "maculo".

\section{Referências Bibliográficas}

Andrade, G. O. \& Duarte, E. Morão, Rosa e Pimenta. Recife, Arquivo Público Estadual de Pernambuco, I956.

Barbosa, Plácido. Dicionário de Terminologia Médica Portuguesa. Rio de Janeiro, Francisco Alves, I9I7.

Campos, M. Notas do Interior do Brasil. Arquivo Brasileiro de Medicina, I9I3.

Chernoviz, P. L. N. Dicionário de Medicina Popular, 6⿳a ed. Paris, A. Roger \& F. Chernoviz, I 890.

CorrêA, M. P. Dicionário das Plantas Úteis do Brasil e das Exóticas Cultivadas, vol. IV.

Rio de Janeiro, Ministério da Agricultura, I984.

Ferreyra, L. G. Erario Mineral, I735. Edição fac-similar do Centro de Memória da

Medicina de Minas Gerais. Belo Horizonte, I997.

Langand, T. J. H. Dicionário de Medicina Doméstica e Popular, $2^{\underline{a}}$ ed. Rio de Janeiro, Laemmert, I 873 .

Manson, P. Maladies des pays chauds. Paris. C. Naud Ed., I904.

Nascentes, A. Dicionário Etimológico Resumido. Rio de Janeiro, InL, 1966. 
Piso, G. História Natural do Brasil Ilustrada. São Paulo, Cia. Editora Nacional, I 948. . História Natural e Médica da Índia Ocidental. Rio de Janeiro, INL, I957.

Raimundo J. O Elemento Afro-negro na Lingua Portuguesa. Rio de Janeiro, Renascença Editora, I933.

Santos Filho, L. História Geral da Medicina Brasileira. São Paulo, Hucitec/Edusp, I99I. São Paulo, F. Linguagem Médica Popular no Brasil. Salvador, Itapuã, I970.

SoAres, A. J. M. Dicionário Brasileiro da Lingua Portuguesa: Elucidário Etimológico Crítico, vol. II. Rio de Janeiro, INL, I955. 